\title{
Modern biotechnology in food
}

\begin{abstract}
The objective of this article was to draw attention and invite the reader's reflexive analysis to identify the ways in which technology influences our diet, with particular emphasis on the biotechnological applications of the food we eat. The aforementioned objective seems too ambitious; however we have tried to carry out a review and a brief and reflexive discussion of the use of biotechnological tools, to arrive in a few lines at the new paradigms of the current era. It is in this context that the terms GMO (Genetically Modified Organism) and TO (Transgenic Organism) are succinctly defined, analyzing the safety of consuming transgenic foods, and if they failed at present, to finally analyze the biotechnological applications in the foods of the future and the bio security that was assumed with commitment and seriousness.
\end{abstract}

Keywords: GMO, transgenic, biology, recombinant DNA, genes
Volume 8 Issue 6 - 2018

\author{
Julio Gabriel-Ortega, Blanca Indacochea- \\ Ganchozo, Yhony Valverde-Lucio, Washington \\ Narváez-Campana \\ Research professors of the Agricultural Engineering Career, \\ Faculty of Natural Sciences and Agriculture, State University of \\ the South of Manabí, Jipijapa, Manabi, Ecuador.
}

\section{Correspondence: Julio Gabriel-Ortega, Faculty of Natural Sciences and Agriculture, State University of the South of Manabí, Jipijapa, Manabi, Ecuador, \\ Email Julio.gabviel@unesum.edu.ec, j.gabviel@proinpa.org}

Received: July 30, 2017 | Published: December 04, 2018

\section{Introduction}

The terms GMO (Genetically Modified Organism) and a TO (Transgenic Organism) are used by most public and scientific publications generically as synonyms and are not always distinguished from them. ${ }^{1,2}$ But, it must be mentioned that both terms are not synonymous and much less equal. An OGM is defined as that organism in which a fragment of DNA (deoxyribonucleic acid) has been removed or added naturally or through conventional breeding. In contrast, an TO is that organism to which genes from a different species have been transferred through the recombinant DNA technique, which would never happen in nature. ${ }^{3}$ Modern plant biology techniques allow identifying the functions of genes in plants, in bacteria and, in general, in any living organism, and incorporate them into a plant to confer new properties. It is well known that in no part of the world, there was opposition to accept transgenic proteins derived from genes of bacteria, plants or humans, produced by bacteria, proteins that reach the blood injected or taken as medicines. This is the case of insulin, interferon, and growth hormone, among others. Some of them already start from the food chain as the chymosin used for the coagulation of cheeses. ${ }^{4}$ In plants, the abundance, color and size of fruits and the plant itself, resistance to certain insects and pathogens, lack of water or excess heat, or even whether the plant is edible or not, all this also has origin in one or several genes of the plant. Nowadays, these genes can be identified within the genetic information of one plant and transferred to another. ${ }^{2}$

\section{Is it safe to consume a transgenic plant?}

Yes it is safe to consume a transgenic plant. This technology is no longer new, although by the way it is frequently approached in the media, on transgenic, is reference is made to the fact that until the last time scientific studies were counted and classified, in 2007, there were about 32.000 published works related to the safety of transgenic plants. These safety investigations began to appear in the scientific literature even before 1996, the date on which commercial production began. ${ }^{5}$ Therefore, almost all countries already have legislation that requires monitoring - for each plant - the way in which, step by step, the plant is genetically improved. Each country also has regulations to authorize its consumption and, of course, its sowing at a commercial level. At the global level, a new discipline emerged: "biosecurity", defined as the set of knowledge that facilitates risk assessment, as well as the legislation and regulation necessary to authorize the safe use of biotechnological processes and genetically modified products. ${ }^{3,6,7}$

\section{The failure of transgenics}

In multiple articles and discussions it was suggested that agriculture based on transgenic seeds is a failure. This is despite the fact that almost 20 million farmers grow more than 170 million hectares in 28 countries with transgenic seeds. ${ }^{7}$ That this is a failure depends on how it is quantified, since in terms of the scope that technology could have had to benefit the health and quality of life of consumers, definitely it is. It is also a failure for the debate to remain involved in terms of the positioning of the large agribusinesses in the field, and not the use of technology for the solution of national problems. This is not the case in countries such as Cuba, Brazil and China ${ }^{4}$ where national companies participate intensively in the development and production of TOs. Technology advances at such giant steps that in this case we talk about a new paradigm that no longer involves bringing genes from other species to plants, but to insert information through RNA interference (ribonucleic acid of interference) that "silences" key genes of the virus and prevents its reproduction: genetically defended plants. It has also been a failure - one would have to admit - that one of the TOs in current production is applied with the same principles that have exhausted the green revolution type production system, although in some cases the use of chemical pesticides has been avoided or diminished for the benefit of the environment, producers and consumers. ${ }^{5}$

\section{Will there be more biotechnology in the foods of the future?}

To more than 20 years of research, and after more than 15 years of production and consumption, it is a failure to continue having to explain that one cannot talk about talking about "transgenic foods" as a whole, and that the Biosecurity is an activity that science assumed with absolute commitment and seriousness; that, paradoxically, regulation and suspicions continue to grow in parallel with the information that ensures their innocuousness. ${ }^{3,4,6,8,9}$ Unfortunately until the day in our country we cannot define what type of biotechnology suits us, establish priorities and, according to our basic needs, establish a policy for the field that allows all sectors work in the same direction. ${ }^{4}$ 


\section{Acknowledgments}

None.

\section{Conflicts of interest}

The authors declare that there are no conflicts of interest. The opinions expressed in this article do not necessarily reflect the official opinion of Southern Man State University of Manabi.

\section{References}

1. Gabriel J. Biotecnología moderna en los alimentos actuales y del mañana. J Selva Andina Biosph. 2014;2(1):23-29.

2. Conner AJ, Glare TR, Nap JP. The release of genetically modified crops into the environment. Part II. Overview of ecological risk assessment. Plant J. 2003;33(1):19-46.
3. Miller K. Biología. Massachusetts: Prentice Hall: 2004;331 p.

4. López-Munguía. A Biotecnología en los alimentos del mañana. Revista Digital Universitaria. 2014;15(8):1607-6079.

5. Levitus G, Echenique V, Rubinstein C, et al. Editors. Biotecnologia y mejoramiento II. Argen Bio, INTA, Argentina: 2004;643 p.

6. UNEP Información sobre el Protocolo de Bioseguridad y marcos regulatorios internacionales: 2014.

7. Tripathi S, Suzuki JNY, Ferreira SA, et al. Papaya ringspot virus-P: Characteristics, pathogennicity, sequence variability and control. $\mathrm{Mol}$ Plant Pathol. 2008;9(3):269-280.

8. Batista JC, Burachik M, Rubinstein C. Evaluación de inocuidad alimentaria de OGMs: Criterios y Recursos para su implementación. United Nations University-ILSI: 2007.

9. REDBIO Marco Regulatorio, para información sobre bioseguridad en América Latina y el Caribe: 2014. 